\begin{tabular}{|lll|}
\hline Diterima & $:$ & 11 November 2019 \\
Direvisi & $:$ & 22 November 2019 \\
Disetujui & $:$ & 20 Desember 2019 \\
Diterbitkan & $:$ & 27 Desember 2019 \\
\hline
\end{tabular}

\title{
KOMPETENSI MOTORIK ANAK USIA DINI: KETERKAITANNYA DENGAN KOGNITIF, AFEKTIF DAN KESEHATAN
}

\author{
Muhammad Munif Syamsuddin'1, Adriani Rahma Pudyaningtyas², \\ Sri Anggarini Parwatiningsih ${ }^{3}$ \\ email: wandamunif@yahoo.com¹, adriani.rahma@staff.uns.ac.id², \\ anggarini@staff.uns.ac.id ${ }^{3}$ \\ Program Studi Pendidikan Guru PAUD Universitas Sebelas Maret Surakarta ${ }^{12}$ \\ Program Studi Kebidanan Universitas Sebelas Maret Surakarta ${ }^{3}$
}

Jalan Ir. Sutami No.36 A, Pucangsawit, Kec. Jebres, Kota Surakarta, Jawa Tengah 57126

\begin{abstract}
Abstrak: Penelitian ini memprediksikan kompetensi motorik (kasar dan halus) terhadap aspek kognitif, afektif dan kesehatan untuk anak usia dini. Pengukuran kompetensi motorik, kognitif dan kesehatan menggunakan tes dan pengukuran afektif menggunakan skala. Partisipan yang dilibatkan adalah anak-anak yang berusia tiga sampai enam tahun $(\mathrm{N}=30)$ dinyatakan sehat secara fisik dan mental dan mendapat persetujuan dari orang tua/keluarga diambil dari taman kanak-kanak di Solo dan Yogyakarta. Data yang sudah terkumpul dianalisis menggunakan regresi untuk mengetahui sebab akibat dari masing-masing variabel. Hasil penelitian ini menunjukkan bahwa kompetensi motorik yang baik berdampak pada aspek kognitif, afektif dan kesehatan anak usia dini. Anak-anak dengan kognitif yang baik ditandai dengan keterampilan pemecahan masalah dengan mengedepankan prososial dalam setiap interaksi. Anak-anak dengan afektif yang tinggi ditandai dengan rasa simpati kepada kawan yang lain dalam bentuk kepedulian. Anak-anak dengan kesehatan yang baik ditandai dengan berkurangnya rasa mengeluh dan aktivitas fisik normal.
\end{abstract}

Kata-kata kunci: afektif, fisik motorik, kesehatan, kognitif

\section{EARLY CHILD COMPETENCY: THE CORRELATION WITH COGNITIVE, AFFECTIVE, AND HEALTH}

\begin{abstract}
This study predicted motor competency (fine and gross) on cognitive, affective and health for early childhood. A test was used to measure motor competency, cognitive and health whereas the affective aspect was measured by scale. The participants of this study involved children aged three to six with good physically and mentally health declared by kindergarten children's parents and families in Solo and Yogyakarta. The data used regression analysis to find out the cause and effect of each variables. The results of this study indicated that good motor competence has an impact on cognitive, affective and early childhood health aspects. Children with a developed cognitive aspect, are characterized by their problem solving in prosocial interaction. High affective children are characterized by their attitude in showing sympathy and care to others. Children with a good health are characterized by their normal physical activity and reduced sense of complaining.
\end{abstract}

Keywords: affective, cognitive, health, motor competency 


\section{PENDAHULUAN}

Setiap anak usia dini dalam keadaan sehat secara fisik dan mental akan terlihat aktif dalam gerak. Mereka akan menunjukkan variasi seperti merangkak, berjalan, berlari, melompat dan sebagainya. Adakalanya keadaan ini sulit dikendalikan oleh para orang tua maupun orang-orang di sekitarnya. Kadang dijumpai saat terjatuh dan terluka namun tetap melanjutkan gerakan-gerakan yang ingin dia lakukan. Anak-anak yang aktif akan menunjukkan aktivitas gerak lebih banyak lagi pada saat mereka bersama dengan teman sebayanya, dan itu sering dijumpai saat mereka berada di sekolah atau taman bermain. Pada saat anakanak menikmati aktivitasnya, maka mereka sekaligus belajar dan mendapatkan pengalaman yang akan membawa pengaruh dalam aspek perkembangannya. Misalnya, secara kognitif anak akan berpikir dalam menyelesaikan masalah, memahami suatu objek maupun pesan dan selanjutnya akan berdampak pada sisi psikologis mereka yaitu senang dan bahagia dengan hasil yang dicapai. Hal ini sesuai dengan teori perkembangan kognitif Piaget yang mengacu pada hubungan yang erat antara kemampuan motorik anak dengan kognitif. Menurut Piaget pengembangan keterampilan motorik memungkinkan anak melakukannya untuk mengeksplorasi lingkungan. Melalui asimilasi dan akomodasi mengarahkan pada konsep kognitif yang baru dan berbeda. Ini mengarahkan pada perkembangan kognitif yang lebih maju (Oberer, Gashaj dan Roebers, 2017). Jadi anak-anak dengan perkembangan fisik dan motorik yang maju akan membantu dalam penguasaan aspek kognitif yang mengantarkan anak dalam memahami dunia menjadi semakin baik. Apabila keadaan ini terus berlanjut maka kesehatan fisik dan mental akan selalu terjaga. Anak-anak yang tumbuh secara sehat akan lebih mungkin dalam mengoptimalkan segala potensi dan keterampilannya.

Studi-studi menunjukkan bahwa aktivitas fisik yang merupakan kebutuhan dasar anak akan menentukan perkembangan fisik dan motoriknya dan juga berhubungan dengan emosional, psikososial dan perkembangan kognitif (Muller, dkk., 2013; Bellows, dkk., 2017; Wehrens, dkk., 2017). Didukung dengan studi dari Cameron, dkk. (Oberer, Gashaj \& Roebers, 2017) menunjukkan bahwa ada hubungan yang positif terkait motorik kasar pada anak berusia tiga sampai empat tahun dengan kemampuan akademik, seperti: matematika, membaca dan pemahaman pada kata. Utesch, dkk. (2016) menyatakan bahwa perkembangan motorik dianggap sebagai faktor penting dalam kesehatan anak secara menyeluruh. Studi lain dari Loprinzi, Davis dan Chieh Fu (2015) menyatakan bahwa pengembangan aktivitas fisik yang memadai akan menjadikan anak-anak menikmati aktivitas fisiknya dan akan memberikan kinerja yang baik dan ini akan berhubungan dengan kemampuan gerak mereka jangka panjang. Ini artinya akan memberikan dampak kesehatan pada anak dalam situasi sekarang maupun yang akan datang.

Dengan demikian sangat penting untuk mengintegrasikan aktivitas fisik ke dalam kehidupan anak-anak dan meletakkan dasar dalam memfasilitasi dan menjaga gaya hidup sehat dalam perjalanan kehidupannya sampai dewasa (Zeng, dkk., 2017). Hal ini sesuai dengan studi yang dilakukan oleh Gaul dan Issartel (2016) yang menyatakan bahwa anak-anak dengan keterampilan motorik yang baik menunjukkan prestasi akademik yang lebih tinggi, prestasi matematika dan perkembangan dalam memahami bacaan. Secara keseluruhan perolehan keterampilan motorik memainkan peranan penting dalam perkembangan anak karena memungkinkan partisipasi dalam pekerjaan sehari-hari seperti bermain, pendidikan dan belajar serta interaksi sosial.

Artikel ini merupakan penelitian yang memfokuskan pada prediksi bahwa antara kompetensi motorik (halus dan kasar) dengan aspek kognitif berhubungan dengan bagaimana anak mengambil keputusan dalam interaksi sosial, aspek afektif berkaitan dengan perasaan simpati kepada orang lain dan aspek kesehatan di mana nanti anak akan sehat secara fisik. Hal ini menjadi penting dan baru untuk dikaji karena anak-anak membutuhkan pelayanan yang maksimal untuk mencukupi kebutuhan perkembangan. Empat aspek perkembangan ini harus bisa berjalan baik, agar anak-anak mampu melewati masa perkembangan dengan optimal yang kemudian akan bermanfaat dalam periode perkembangan selanjutnya.

Secara khusus penelitian ini ingin mengembangkan aspek psikologi positif yaitu mengembangkan anak-anak dari sehat menjadi sangat sehat (good to great). Hal ini agar anak-anak yang sehat tidak merasa rugi harus menunggu mereka yang kurang aktif di dalam pembelajarannya. Anakanak yang sehat akan ditangani secara serius agar pertumbuhan dan perkembangannya dapat optimal. Kajian dalam penelitian ini akan mengungkapkan 
dampak potensi yang dimiliki anak dan keterkaitannya dengan aspek perkembangan yang akan anak kuasai. Akhirnya anak-anak akan mendapatkan kepuasan hidup yaitu dapat berkembang sesuai dengan tahapan perkembangannya secara optimal.

\section{Kajian Pustaka}

Perkembangan adalah proses seumur hidup dari berbagai aspek fisik, motor, kognitif, emosi dan lain sebaginya yang selalu berhubungan erat dan tergantung dari seberapa jauh interaksi dari gen, lingkungan, dan sosial budaya (Dordic, Tubic, \& Jaksic, 2016). Masa kanak-kanak atau biasa disebut masa anak usia dini berlangsung dari usia nol sampai enam tahun. Pada setiap tahapan perkembangannya, anak mengalami kemajuan dalam berbagai aspek perkembangan. Agar anak mampu melewati tahapantahapan perkembangannya dibutuhkan keterlibatan orangtua, guru maupun lingkungan yang mengelilingi yang mampu memberikan kontribusi yang positif (Dirjen PAUDNI, 2010). Menurut Hurlock (1980) awal masa anak-anak merupakan masa yang ideal untuk mempelajari keterampilan tertentu. Terdapat tiga alasan, pertama, mengulang-ulang aktivitas sampai terampil. Kedua, anak-anak bersifat pemberani sehingga tidak terhambat oleh rasa takut. Ketiga, anak mudah dan cepat belajar karena tubuhnya yang lentur dan keterampilan yang dimiliki baru sedikit, sehingga keterampilan yang baru dikuasai tidak mengganggu keterampilan yang sudah ada. Hal ini menunjukkan bahwa anak sejak kecil mempunyai potensi yang bisa tumbuh dan berkembang.

Hal ini sejalan dengan studi dari Zachopoulou, Tsapakidou dan Derri (2004), menyatakan masa kanak-kanak sangat penting untuk pengembangan dasar keterampilan motorik. Hal ini karena (a) keterampilan tersebut membentuk dasar kesuksesan untuk masa remaja dan dewasa, (b) anak-anak sedang dalam periode menikmati waktu belajar, (c) jika sukses, maka ini akan dipertahankan seumur hidup. Jika individu sering mengalami kegagalan selama hidupnya karena mereka sering mengalami kegagalan pada saat periode awal perkembangannya.

Teori lain yaitu dari teori motivasi kompetensi Harter (Breslin, dkk.,2012) menyatakan bahwa, jika seorang anak memiliki persepsi diri yang positif dan percaya bahwa mereka telah menguasai kinerja perilaku yang diarahkan pada tujuan, mereka akan lebih cenderung termotivasi untuk mengulang perilaku itu. Menerapkan teori Harter, kerangka kerja untuk kompetensi keterampilan motorik akan menunjukkan bahwa, jika seorang anak diperlihatkan bagaimana cara melompat, menendang atau menangkap bola dan mereka belajar untuk melakukan keterampilan, berhasil mendorong umpan balik positif dari orang dewasa dan teman sebaya maka anak cenderung memiliki persepsi diri positif dan termotivasi untuk mengulanginya perilaku itu. Sebaliknya, dikatakan jika anak memutuskan untuk menghindari aktivitas motorik, permainan dan olah raga maka akan menyebabkan kegagalan dan rendahnya pemahaman diri dan ini akan berhubungan dengan dampak kesehatan yang dialami.

Dari penjelasan di atas dapat diambil kesimpulan bahwa langkah penting dalam mengembangkan anak-anak adalah memulainya pada saat anak-anak masih pada tahap awal perkembangan. Anak-anak yang menunjukkan kompetensi yang baik sejak dini akan lebih mudah dalam penyesuaian diri dengan lingkungan. Jadi anak akan secara aktif belajar mengenal dunia, merasakan senang saat beraktivitas maka ini menjadi cara yang beralasan untuk membantu meningkatkan kesehatan fisik mereka.

Pengembangan keterampilan motorik dasar telah menjadi salah satu studi beberapa tahun terakhir yang telah menarik perhatian orang tua, pendidik, peneliti dan spesialis di bidang ini. Zeng, dkk. (2017) menyatakan aktivitas fisik sangat mendasari bagi perkembangan awal setiap anak dan memengaruhi banyak aspek kesehatan anak. Utesch, dkk. (2016) menyatakan perkembangan motorik secara taksonomi dibagi menjadi tiga, (a) kemampuan gerak berpindah, (b) keterampilan motorik dan (c) kemampuan motorik umum. Kemampuan gerak berpindah didefinisikan sebagai kelompok gerakan yang memiliki pola tujuan dan diarahkan secara khusus melalui instruksi dan praktik.

Kemampuan motorik digambarkan sebagai sifat umum atau kapasitas individu yang mendasari kinerja dari berbagai keterampilan gerakan. Kemampuan motorik umum adalah mengatur semua kemampuan gerak yaitu kemampuan gerakan berpindah dan keterampilan gerak digunakan secara bergantian. Dalam konteks kompetensi motorik maka dianggap sebagai kemampuan motorik umum. Selanjutnya, menurut Loprinzi, Davis dan Chieh Fu (2015) kompetensi motorik digambarkan dengan pengembangan kemampuan anak untuk memahami secara cerdas dan merespon secara efektif tuntutan fisik yang dbutirui dalam kehidupan sehari-hari.

Mengacu pada teori Piageat (Santrock, 2007) menyatakan bahwa anak-anak dalam perkembangannya dapat dijelaskan melalui empat tahapan. Pertama, sensori motorik (0-2tahun). Dalam tahap ini anak membangun pemahaman mengenai 
dunia dengan mengkoordinasikan pengalaman sensoris dengan tindakan fisik motorik. Kedua, praoperasional (2-tahun). Pada tahap ini anak mulai menjelaskan dunia dengan kata-kata, gambar dan lukisan. Ketiga, operasional konkrit (7-11tahun) yaitu anak dapat melakukan operasi dan penalaran logis. Keempat, operasional formal (7-15tahun). Pada tahap ini individu lebih melampaui pengalaman konkret dan berpikir dalam istilah yang abstrak dan lebih logis. Teori ini bisa dimaknai bahwa pengalaman anak-anak yang baik pada tahapan awal kehidupannya akan mempengaruhi pada tahapan selanjutnya. Misalnya, gerak fisik motorik yang baik sebagai akibat dari stimulasi yang ditangkap oleh sensor akan berdampak pada pemahaman pada suatu objek tertentu. Anak-anak akan dengan mudah mengembangkan kemampuannya berdasarkan pada pemahaman objek yang diterimanya.

Dalam penelitian ini perkembangan kognitif yang maksud berhubungan dengan pemecahan masalah sosial anak. Mengacu pada studi dari Walker, Degnan, Fox, Henderson (2013) menyatakan bahwa pengembangan keterampilan pemecahan sosial pada anak penting untuk masalah sosial sehari-hari anak dapat mempengaruhi kualitas hidup mereka, misalnya pengalaman sosial. Hal ini tidak terlepas dari lingkungan yang mengelilingi anak baik orang tua, guru maupun teman sebaya. Ketika anak-anak mendapatkan masalah dalam interaksi sosial, maka di dalam pengambilan keputusan anak-anak lebih memilih menggunakan strategi prososial dan lebih kooperatif dibanding dengan strategi yang agresif.

Dalam penelitian ini aspek emosi yang menjadi fokus berkaitan dengan motivasi moral dan simpati. Malti, dkk. (2009) menguraikan bahwa motivasi moral memiliki komponen kognitif yang kuat karena pertamatama anak harus mengerti aturan moral. Simpati yang kemudian sering dipanggil empati adalah kemampuan individu untuk meringankan beban orang orang lain dan memahami apa yang dirasakan orang lain. Dalam konteks ini motivasi moral dan simpati membutuhkan kemampuan dalam mengambil peran dan karenanya keduanya saling terkait. Anak-anak motivasi moral dan simpati yang tinggi akan berpengaruh kepada perilaku yang lain seperti prososial.

Penelitian ini menduga bahwa kompetensi motorik anak yang baik akan mengembangkan sisisisi afektif anak di mana mereka akan menunjukkan perilaku emosi yang positif. Anak -anak yang stabil dalam pemecahan masalah yang dihadapi dan mampu beradaptasi dengan lingkungan sosial yang mengelilingi.
Kesehatan sangat berperan penting dalam aspek perkembangan anak. Kesehatan bisa didapatkan memalui beberapa faktor. Santrock (2007) menerangkan (a) pembentukan kebiasaan yang sehat pada masa kanak-kanak seperti memakan makanan yang rendah lemak dan kolesterol dan melakukan olah raga secara teratur akan memberikan kontribusi pada penundaan sebuah sebuah penyakit, (b) nutrisi dan perilaku makan, dimana bagi bayi pentingnya memperoleh energi dan gizi yang cukup dalam lingkungan yang penuh kasih sayang akan membuat mereka lebih terjamin kesehatannya, dan (c) ASI sangat berperan penting di dalam menjaga kesehatan bayi dan keuntungan-keuntungan yang bisa didapat adalah pertambahan berat yang pas, lebih sedikit alergi, pecegahan atau penurunan diare, infeksi pernafasan, infeksi saluran kencing, infeksi karena bakteri. Keuntungan lain adalah tulang yang lebih padat di masa kanak-kanak dan dewasa dan ketajaman visual serta perkembangan neurologis dan kognitif yang meningkat.

Anak-anak dengan kesehatan cukup akan menjadikan anak sehat secara fisik dan terampil dalam banyak kegiatan dalam setiap aktivitas. Selanjutnya anak-anak dengan kompetensi motorik yang tinggi akan berdampak pada kesehatannya.

Kompetensi motorik memainkan peranan penting dalam aspek perkembangan. Studi dari Payne dan Rink (dalam Zachopoulou, Tsapakidou, \& Derri, 2004) menunjukkan bahwa kompetensi motorik yang berkembang akan meningkatkan perkembangan psikologis, sosial, kognitif dan afektif. Herrman, Heim dan Seelig (2017) menyatakan bahwa kompetensi motorik sangat berhubungan dengan kesehatan, kebugaran dan kestabilan berat badan. Studi ini diperkuat oleh Zeng, dkk. (2017) yang menyatakan bahwa kompetensi motorik erat hubungannya dengan berbagai kesehatan yang dirasakan, kebugaran dan pengembangan kognitif yang baik. Secara singkat keterkaitan tersebut dapat diringkas dalam gambar berikut :

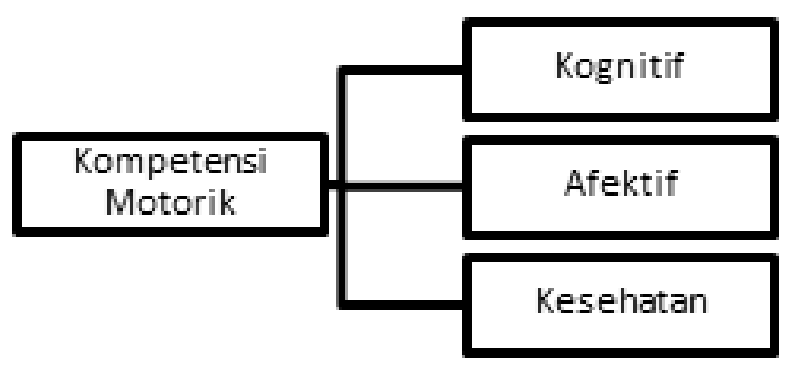

Gambar 1. Keterkaitan Keterkaitan antara Kompetensi Motorik, Kognitif, Emosi dan Kesehatan 


\section{METODE PENELITIAN}

Partisipan dalam penelitian adalah anakanak usia tiga sampai enam tahun diambil dari Taman Kanak-Kanak (TK) atau lembaga PAUD di Surakarta dan Yogyakarta, yang masih aktif dalam kegiatan sekolah dan dinyatakan sehat secara fisik dan mental. Hal ini penting, karena fokus penelitian ini mengembangkan anak-anak yang sehat menjadi sangat sehat. Pengambilan data diambil dengan menggunakan random assignment dan semua partisipan mendapat persetujuan dari keluarga. Jumlah partisipan yang dilibatkan dalam penelitian ini adalah 30 anak yang diambil secara acak dari ketiga taman kanak-kanak tersebut.

Variabel bebas dalam penelitian ini adalah kompetensi motorik anak usia dini dan sebagai variabel terikat adalah kognitif, afektif dan kesehatan. Pengukuran variabel kompetensi motorik mengacu pada Utesch, dkk (2016) yang membagi kompetensi motorik menjadi dua yaitu motorik kasar dan halus yang selanjutnya dibagi dalam beberapa aspek yang diukur. Tabel berikut menjelaskan domain dan butir pengukuran:

Tabel 1.

Domain dan Butir Pengukuran

\begin{tabular}{ll}
\hline \multicolumn{1}{c}{ Domain } & \multicolumn{1}{c}{ Butir Pengukuran } \\
\hline Motorik Halus & - Menempatkan titik pada selem- \\
& bar kertas \\
& - Menggenggam tisu \\
& - Memindah permainan \\
\hline Kelincahan & - Memindah bola dari kotak ke \\
dan koordinasi & kotak \\
& - Melewati sebuah lingkaran \\
& - Melompat \\
& - Berguling kesamping di atas \\
& lantai \\
& - Melompat masuk dan keluar \\
& dari sebuah lingkaran \\
\hline Keseimbangan & - Berjalan maju pada sebuah \\
& garis \\
& - Berjalan mundur pada sebuah \\
& garis \\
& - Melompat dengan satu kaki \\
& - Berdiri dan duduk sambil me- \\
& megang bola di kepala \\
& - Melompat masuk dan keluar \\
& dari sebuah lingkaran \\
\hline Wekuatan & - Menangkap tongkat \\
& - Menangkap cincin \\
\hline & - Melompat tali \\
& - Melompat masuk dan keluar \\
& dari sebuah lingkaran \\
\hline
\end{tabular}

\begin{tabular}{ll}
\hline Kecepatan & - Menempatkan titik pada selem- \\
& bar kertas \\
& - Melompat ke samping dengan \\
& tali \\
& - Memindah bola dari kotak ke \\
& kotak \\
\hline Ketepatan & - Melempar bola pada target \\
& - Memindahkan permainan \\
\hline
\end{tabular}

Variabel kognitif mengacu pada bagaimana anak-anak mampu membuat pemecahan masalah dalam hubungannya dengan sosial. Pengukuran menggunakan studi yang dinyatakan oleh Walker, dkk. (2013) yang mana diubah sesuai dengan keadaan partisipan dan setting penelitian. Aspek kognitif diuji dengan menggunakan tes yang mengukur bagaimana anak-anak bertemu dengan situasi tertentu dan harus memberikan keputusan pemecahan masalah yang dipilih yaitu apakah mereka akan memilih prososial atau agresif. Pertanyaan seperti "apakah adik akan memberikan maaf kepada teman yang berbuat salah atau akan membalas di lain waktu" akan merangsang anak untuk berpikir terlebih dahulu sebelum membuat keputusan untuk pemecahan masalah. Uji coba butir dilakukan kepada 30 partisipan dan didapatkan koefisien korelasi butir total 0.281 dan tertinggi 0.614 dengan reliabilitas 0.714 . Penentuan butir yang baik didasarkan pada batas kriteria korelasi butir total 0.20 (Azwar, 2004). Keseluruhan butir pemecahan masalah kemudian dugunakan untuk penelitian dengan 30 partisipan dan menghasilkan koefisen korelasi butir total terendah 0.313 dan tertinggi 0.673 dengan reliabilitas 0.722 .

Pengukuran aspek afektif (motivasi moral/ simpati) mengacu kepada studi Malti, dkk. (2009) yaitu laporan anak-anak (self report, penilaian dari ibu/orang tua anak dan penilaian dari guru) dan disesuaikan dengan keadaan. Studi tersebut menyatakan bahwa motivasi moral dan simpati saling terkait karena samasama membutuhkan kemampuan untuk mengambil peran. Simpati dipandang sebagai intisari emosi moral dan dianggap sebagai penyebab perilaku moral. Pengukuran simpati yang digunakan dalam penelitian ini berfokus kepada perasaan peduli dan mampu memahami keadaan orang lain yang dimaksutkan untuk bisa meringankan emosi negatif orang lain. Anak-anak disediakan delapan butir peryataan di mana jika menjawab "ya" diberikan skor 1 dan menjawab "tidak" diberikan skor 0 . Pernyataan "kasihan melihat kawan lain yang jatuh" dan "mengucapkan selamat 
kepada teman yang berhasil menyelesaikan tugas" menjadi contoh butir butir yang ditujukan kepada anak. Anak-anak yang menjawab "ya" diberikan skor 1 dan yang menjawab "tidak" diberikan skor 0 . Keseluruhan butir menghasilkan koefisien korelasi butir total terendah 0.361 dan tertinggi 0.530 dengan reliabilitas 0.743 . Butir dinyatakan baik jika memenuhi batas kriteria korelasi butir total 0.3 (Azwar, 2004). Untuk memperkuat jawaban anak, butir pernyataan ini juga diberikan kepada orang tua dan guru dengan contoh butir pernyataannya adalah "anakku mudah iba jika melihat kawannya terluka".

Pengukuran kesehatan anak diukur dari berkurangnya rasa mengeluh yang dialami oleh anak dan ditentukan dengan keputusan dokter.

Prosedur penelitian ini adalah meminta izin kepada sekolah dan orang tua siswa untuk berkenan putra/putrinya atau siswa diikutsertakan sebagai partisipan. Penelitian ini melibatkan bantuan dari beberapa pihak, yaitu: (1) Para guru TK/PAUD diminta untuk memberikan permainan yang didalam permainan itu ada unsur fisik, kognitif dan afektif, (2) Psikolog perkembangan anak dilibatkan untuk memberikan bimbingan dan konseling pada anak, dan (3) Dokter.
Pada kegiatan fisik motorik (halus dan kasar) anak-anak akan dipandu oleh guru dan tim yang professional yang akan mengarahkan mereka. Kemudian anak- anak diminta melakukan gerakangerakan secara bergantian dari kegiatan yang sudah direncanakan dalam waktu 30-50 menit dalam bentuk permainan untuk setiap kegiatan. Dalam satu minggu ada tiga sesi kegiatan dengan hari yang berbeda. Kegiatan ini akan berlangsung enam bulan. Setiap dua minggu sekali akan dilakukan tes kognitif, afektif dan kesehatan.

Data yang sudah diambil dianalisis menggunakan teknik statistik regresi untuk mengetahui sebab akibat dari masing-masing variabel. Sebelum dianalisis, akan dilakukan uji normalitas untuk memastikan data terdistribusi normal dan uji linieritas untuk memastikan hubungan-hubugan varibel bebas dan variabel tergantung adalah linier.

Hipotesis Penelitian: "Ada hubungan antara kompetensi motorik anak usia dini dengan kognitif, afektif dan kesehatan mereka. Anak-anak dengan kompetensi motorik yang baik akan berkaitan dengan kemampuan kognitif, afektif dan kesehatan mereka".

\section{HASIL DAN PEMBAHASAN}

Uji normalitas dilakukan pada tiga variabel yaitu kompetensi motorik, kognitif dan afektif dengan menggunakan Kolmogorof-Smirnof dan hasilnya normal $(\rho \geq 0.05)$. Sementara uji linieritas dilakukan untuk mengetahui linier atau tidaknya hubungan antara kompetensi motorik, kognitif dan afektif. Linieritas dinyatakan diterima dengan menggunakan kaidah signifikansi dari deviation from linearity dan hasilnya linier $(\rho \geq 0.05)$.

Tabel 2.

Uji Regresi Kompetensi Motorik, Kognitif, dan Kesehatan

\begin{tabular}{lcccc}
\hline Variabel & $\begin{array}{c}\text { Kompetensi } \\
\text { Motorik }\end{array}$ & Kognitif & Afektif & $\rho$ \\
\hline $\begin{array}{l}\text { Kom- } \\
\text { petensi }\end{array}$ & & $0.851^{* *}$ & $0.686^{* *}$ & 0.000 \\
Motorik & & & & \\
\hline
\end{tabular}

Ket : $\rho \leq 0.01$

Tabel di atas menunjukkan hubungan yang kuat antara tiga veriabel yaitu kompetensi motorik, kognitif dan afektif.

Sementara untuk tes kesehatan anak, rata-rata usia anak yang diperiksa adalah 5 tahun lebih 5 bulan, dengan anak berumur kurang dari lima tahun sejumlah
$9(30 \%)$ dan anak berumur lebih dari 5 tahun sejumlah 21 anak (70\%). Pembagian kelompok umur bertujuan untuk mempermudah analisis data sesuai dengan klasifikasi interpretasi status gizi WHO 2008.

Pemeriksaan yang dilakukan meliputi pemeriksaan berat badan, tinggi badan, dan lingkar lengan atas. Rata-rata berat badan pada anak berusia $<5$ tahun adalah $16.2 \mathrm{~kg}$ dan $>5$ tahun adalah $17.8 \mathrm{~kg}$. Analisis menggunakan chart WHO dengan interpretasi $Z$ skor=7berat badan (hanya untuk anak diusia kurang dari 5 tahun) berdasarkan usia menunjukkan bahwa seluruh anak berusia $<5$ tahun yang berjumlah 9 anak memiliki nilai yang normal. Rata-rata tinggi badan pada anak berusia $<5$ tahun adalah $106.6 \mathrm{~cm}$ dan $>5$ tahun adalah $112.4 \mathrm{~cm}$. Analisis menggunakan chart WHO dengan interpretasi $Z$ skor tinggi badan berdasarkan usia menunjukkan bahwa 9 anak normal (semua anak yang berusia $<5$ tahun). Sementara rata-rata BMI (Indeks Masa Tubuh) pada anak berusia $>5$ tahun adalah 14.04. Rata-rata WHZ (kepanjangan dan definisinya) pada anak usia $<5$ tahun adalah 9 anak tergolong normal. Analisis menggunakan chart WHO dengan interpretasi $Z$ skor berdasarkan BMI (hanya untuk anak berusia $>5$ tahun) menunjukkan bahwa 15 anak normal, 2 anak dalam kategori severely wasted 
dan 2 anak (wasted), dan 2 anak tergolong overweight. Data tersebut menunjukkan bahwa kesehatan anak baik dan ini berarti tumbuh kembang anak adalah normal.

Penelitian ini berusaha untuk mengembangkan psikologi positif untuk pelayanan pada anak usia dini yaitu dengan merubah anak-anak dari sehat menjadi sangat sehat (good to great). Selama ini banyak kajian yang disebut psikologi negatif yang berusaha menyembuhkan anak dari sakit menjadi sehat, dari kemampuan rata-rata menjadi pintar. Penelitian ini berkontribusi untuk memberikan keadilan terhadap pelayanan kepada anak. Mereka tidak hanya disembuhkan dari penyakit, tetapi bagi anak-anak yang sehat dan bahkan di atas rata-rata harus diperhatikan dikembangkan potensinya agar mereka menjadi anakanak yang hebat.

Penelitian ini memprediksi kompetensi motorik anak usia dini yang meliputi motorik halus, kelincahan dan koordinasi, keseimbangan, waktu reaksi, kekuatan, kecepatan dan ketepatan terhadap aspek kognitif, afektif dan kesehatan. Hasil menunjukkan secara bersama-sama kompetensi motorik dapat memprediksi kognitif, afektif dan kesehatan anak usia dini dan penelitian ini mendukung studi-studi sebelumnya (Herrman, Heim dan Seelig, 2017; Zeng, dkk., 2017; Zachopoulou, Tsapakidou, \& Derri, 2004).

Penelitian ini mengedapankan intervensi , kedekatan dan ketulusan bertemu kepada anak yang mendalam akan memberikan penerimaan anak yang tinggi. Sebelum dilakukan tes, anak-anak diberikan perlakuan dan intervensi sedemikian rupa agar mereka memahami konteks masalah. Dalam kegiatan fisik motorik, anak dibekali pemahaman bagaimana harus melewati suatu tantangan gerak, sehingga mereka tidak hanya sekedar bisa bergerak dari satu tempat ke tempat yang lain melainkan mereka mempuyai kompetensi untuk menghasilkan pola-pola gerakan tertentu dan menjadi lebih efektif dan efisien dalam menyelesaikan tugas. Hasil menunjukkan kompetensi motorik anak berhubungan sangat kuat dengan aspek koginif, afektif dan kesehatan. Tingkat pencapaian aspek kognitif yang dalam hal ini berhubungan dengan pemecahan masalah yang dilakukan oleh anak mengalami kenaikan yang signifikan dibanding dengan data observasi awal. Demikian juga yang berhubungan dengan emosi, anak-anak meningkat di dalam memahami dan memperlakukan orang lain dalam bentuk simpati. Dalam hal kesehatan anakanak menunjukkan berukurangnya secara drastis dari perasaan mengeluh dengan kesehatannya dan menunjukkan aktivitas fisik yang normal. Penelitian ini juga memperkuat teori terbaru bahwa kognisi, persepsi, gerak motorik dan emosi mempunyai hubungan sangat kuat (Dordic, Tubic \& Jaksic, 2016).

Beberapa hal yang menjadi alasan hipotesis ini terbukti adalah pertama, anak- anak yang dijadikan partisipan dalam penelitian ini adalah mereka yang yang sejak awal sudah dinyatakan secara sehat baik fisik dan mentalnya. Artinya mereka sudah siap untuk mendapatkan beberapa treatment dan pengujian dalam penelitian. Anak-anak yang secara fisik dan mental sehat akan lebih mudah mengikuti tahapan perkembangan dan mampu menguasai aspek perkembangan secara lebih cepat. Karena itu program pendidikan yang sesuai untuk perkembangan fisik, motorik, kognitif dan afektif harus lebih difokuskan (Sheikh, Safania \& Afshari, 2011). Kedua, dinamika yang tejadi selama kegiatan penelitian berlangsung bertemu dengan anak-anak yang dengan senang hati dan aktif menikmati semua pelatihan yang diberikan. Mereka menunjukkan ekspresi alamiah dimana saling berebutan dalam setiap kegiatan meskipun urutan tugas yang seharusnya dia kerjakan belum saatnya tiba pada gilirannya. Anak-anak yang sehat fisik dan motoriknya akan menunjukan intensi pada suatu kegiatan tertentu. Zachopoulou, Tsapakidou dan Derri (2004) menyatakan keterampilan motorik dasar signifikan karena (a) anak-anak membentuk dasar untuk sukses dalam keterampilan gerak selama masa remaja dan dewasa, (b) anak-anak senang mempelajarinya, dan (c) setelah dipelajari, akan dipertahankan untuk melanjutkan tahapan selanjutnya. Jika anak gagal dalam periode perkembangan ini maka kemungkinan besar akan mengalami kesulitan pada saat remaja. Intinya, ketika anak ikut aktif ambil bagian dalam aktivitas motorik, aspek sosial mereka berkembang karena sukses melakukan interaksi dengan yang lain seperti membantu, bekerjasama dan belajar mengendalikan agresi. Ketiga, penelitian ini dilakukan pada sekolah taman kanak-kanak yang sudah eksis di tengah-tengah kehidupan masyarakat. Sekolah yang positif membawa dampak bagi anakanak dalam proses belajar dan berkembang. Ketika sekolah memberikan fasilitas yang luas kepada anak-anak maka akan memberikan pengalaman yang berarti selama mereka masih sekolah (Leeper, Skipper \& Witherspoon, 1979). Keempat, anak-anak yang terlibat dalam penelitian ini dikelilingi oleh keluarga dengan rata-rata berpendidikan, status ekonomi sosial baik dan berasal dari daerah yang kondusif dimana 
akses untuk kebutuhan hidup mudah terpenuhi. Hal ini menunjukkan bahwa kebutuhan-kebutuhan dasar anak tercukupi, dari kebutuhan kasih sayang, nutrisi, keamanan dan lain-lain. Dengan lingkungan yang demikian maka anak-anak akan tumbuh dengan cepat baik fisik motorik, kognitif, afektif dan kesehatan. Hal ini mendukung studi-studi sebelumnya, misalnya bahwa sekolah di wilayah berpenghasilan tinggi akan akan memiliki sumber daya yang baik (Santrock, 2007). Kelima, dari hasil selama kegiatan penelitian berlangsung nampak jelas ketika anakanak dengan kompetensi motorik baik, maka mereka akan mempunyai rasa ingin tahu yang tinggi terhadap sesuatu yang ditunjukkan dan memiliki minat untuk mencoba melakukan. Mereka juga menunjukkan keterampilan pemecahan masalah yang baik dan simpati kepada orang lain yang tinggi.

Ketika anak-anak dibuatkan sebuah kelompok untuk menyelesaikan tugas tertentu maka mereka mempunyai semangat yang tinggi untuk bekerja dengan kawan lain dan kerjasama dalam tim sangat kuat. Mereka saling berdiskusi untuk menyelesaikan persoalan yang diberikan dan mengambil keputusan dengan cara yang disepakati dalam kelompok tersebut. Dampak dari kondisi yang demikian berpengaruh terhadap kondisi kesehatan anak-anak. Mereka terlihat riang dan lincaj dalam aktibitas. Secara mental anakanak menjadi sangat terhibur dan keinginan untuk mengulangi kegiatan dan memilih kawan untuk berada dalam kelompoknya dan terjadi kompetisi yang sehat diantara mereka. Secara fisik, anak-anak dinyatakan sehat dengan ditandainya jarang mengalami rasa sakit. Hal ini terbukti dari presensi kehadiran dan bukti keikutsertaan dalam setiap pembelajaran baik di sekolah maupun di luar sekolah. Hasil wawancara dengan orang tua anak menyatakan jika anak-anak mereka ketika di rumah menunjukkan kesehatan fisik yang baik, misalnya jarang mengeluh mengenai kondisi fisiknya. Dari data penelitian pun menunjukkan bahwa anak-anak mengalami pertumbuhan yang normal. Peran sekolah sangat penting memberikan budaya yang sehat kepada anak-anak, para orang tua dan lingkungan sekitar. Sistem budaya tertentu akan menentukan kekuatan invidivu (Snyder \& Lopez, 2007).

Hasil penelitian ini memperkuat studistudi tentang psikologi positif yang berusaha mengembangkan anak-anak dari kondisi yang sehat menjadi superior. Pada saat anak-anak memiliki kompetensi motorik yang baik maka ini akan membawa pengaruh kepada perkembangan dan perilaku dalam masa tumbuh kembang. Akhirnya, penlitian ini memberikan petunjuk bahwa pelayanan dan pendampingan kepada anak akan memberikan dampak sangat berarti dalam melewati masa tumbuh kembang. Kompetensi motorik yang baik akan membawa anak-anak pada tingkat kognitf, afektif dan kesehatan yang baik pula.

\section{PENUTUP}

Dari hasil dan pembahasan dapat diambil kesimpulan bahwa kompetensi motorik baik halus maupun kasar tidak terlepas dari aspek perkembangan anak yang lain seperti aspek kognitif, afektif dan kesehatan anak. Aspek kognitif berhubungan dengan meningkatnya keterampilan pemecahan masalah dengan memilih sikap prososial dalam situasi yang dijumpai. Aspek afektif berhubungan dengan rasa simpati anak yang tinggi ketika berhadapan dengan orang lain khususnya teman sebaya. Kesehatan anak berhubungan dengan berkurangnya rasa mengeluh dan sktivitas fisik yang normal. Dengan demikian penelitian ini menunjukkan hasil bahwa kompetensi motorik berhubungan kuat sehingga mampu memprediksikan aspek kognitif (pemecahan masalah), afektif (simpati) dan kesehatan anak yang normal.
Studi-studi tentang psikologi positif yaitu usaha mengembangkan individu dari sehat menjadi sangat sehat khususnya dalam lingkup anak usia dini masih jarang dilakukan. Penelitian ini menunjukkan bahwa ketika anak-anak dinyatakan sehat baik secara fisik dan mental maka pertumbuhan dan perkembangan akan mudah dikuasai. Anak-anak dengan kompetensi motorik yang baik akan berhubungan dengan aspek perkembangan yang lain yaitu kognitif, afektif dan kesehatan. Sekolah yang positif, keluarga dengan kelekatan yang tinggi, nutrisi terjamin, lingkungan yang kondusif dan budaya yang maju berperan sangat penting dalam membantu tumbuh kembang. Anakanak dengan kesehatan fisik dan mental baik akan meramalkan kekuatan pada masa perkembangannya selanjutnya. 


\section{DAFTAR PUSTAKA}

Azwar, S. (2004). Penyusunan Skala Psikologi. Pustaka Pelajar : Yogyakarta.

Bellows, L., L., Davies, P. L., Courtney, J. B., Gavin, W. J., Johnson, S. L., \& Boles, R. E. (2017). Motor skill development in low-income, at-risk preschoolers: A community-based longitudinal intervention study. Journal of Science and Medicine in Sport. 20. 997-1002.

Breslin, G., Murphy, M., McKee, D., Delaney, B., \& Dempster, M. (2012). The effect of teachers trained in a fundamental movement skills programme on children's self-perceptions and motor competence. European physical education review. 18(1) 114-126.

Dirjen PAUDNI. (2010). Peraturan Menteri Pendidikan Nasional tentang standar pendidikan anak usia dini. Kementrian Pendidikan Nasional : Jakarta.

Dordic, V., Tubic, T, \& Jaksic, D. (2016). The relationship between physical, motor, and intellectual development of preschool children. Procedia Social and Behavioral science. 233. 3-7.

Gaul, D. \& Issartel, J. (2016). Fine motor skill proficiency in typically developing children: On or off the maturation track?. Human Movement science. 78-85.

Herrmann, C., Heim, C. \& Seelig, H. (2017). Construct and correlates of basic motor competencies in primary school-aged children. Journal of Sport and Health Science. 20. 1-8.

Hurlock, E. (1980). Perkembangan anak. Terjemahan. Edisi kelima. Erlangga : Jakarta.

Leeper, S. H., Skipper, D. S., \& Witherspoon, R. L., (1979). Good schools for young children. Fourth edition. Mcmillan Publishing Co., Inc : USA.

Loprinzi, P. D, Davis, R. E. \& Chieh Fu, Y. (2015). Early motor skill competence as a mediator of child and adult physical activity. Preventive Medicine Report. 2. 833-838.Herrmann, C., Heim, C. \& Seelig, H. (2017). Construct and correlates of basic motor competencies in primary schoolaged children. Journal of Sport and Health Science. 20. 1-8.

Malti, T., Gummerum, M., Keller, M., \& Buchmann, M. (2009). Children's moral motivation, sympathy, and prosocial behavior. Journal Compilation. 2 (80) $442-460$.
Muller, J., Pringsheim, M., Engelhardt, A., Meixner, J., Halle, M., Oberhoffer, R., Hess, J., \& Hager, A. (2013). Motor training of sixty minutes once per week improves motor ability in children with congenital heart disease and retarded motor development: a pilot study. Cardiology in the Young. 23. 717-721.

Oberer, N., Gashaj, V., \& Roebers, C. M., (2017). Motor skills in kindergarten: Internal structure, cognitive correlates and relationships to background variables. Human Movement Science. 52. $170-180$.

Santrock, J. W. (2007). Perkembangan anak. Edisi kesebelas. Erlangga : Jakarta.

Sheikh, M., Safania, A. M., \& Afshari, J. (2011). Effect of selected motor skills on motor development of both genders aged 5 and 6 years old. Procedia and Behavioral science. 15. 1723-1725.

Snyder, C. R., \& Lopez, S. J., (2007). Positive psychology. The scientific and practical explorations of human strengths. Sage Publications Inc. : USA

Utesch, T., Bardid, F., Huyben, F., Strauss, B., Tietjens, M., Martelaer, K. D., Seghers, J., \& Lenoir, M. (2016. Using Rasch modeling to investigate the construct of motor competence in early childhood. Psychology of Sport and Exercise. 24. 179-187.

Walker, O. L., Degnan, K. A., Fox, N. A., \& Henderson, H. A. (2013). Social problem solving in early childhood: Developmental change and the influence of shyness. Journal of Applied Developmental Psychology. 34. 185-193

Wehrens, B. B., Dordel, S., Schickendantz, S., Krumm, C., Bott, D., Sreeram, N., \& Brockmeier, K. (2007). Motor development in children with congenital cardiac diseases compared to their healthy peers. Cardiol Young. 17. 487-498.

Zachopoulou, E., Tsapakidou, A., \& Derri, V. (2004). The effects of a developmentally appropriate music and movement program on motor performance. Early Chilhood ResearchQuarterly. 19. 631-642.

Zeng, N., Ayyub, M., Sun, H., Wen, X., Xiang, P., \& Gao, Z. (2017). Effects of physical activity on motor skills and cognitive development in early childhood: A systematic review. BioMed 
Kompetensi Motorik Anak...

132 Jurnal IImiah VISI PGTK PAUD dan Dikmas - Vol. 14 No. 2, Desember 2019 